\title{
Comparison of Motivation and Students' Learning Achievements by using E-Learning based Schoology and Power Point on Biology Material
}

\author{
Asmariati Purba ${ }^{1}$, Herbert Sipahutar ${ }^{2}$, Syahmi Edi ${ }^{2}$ \\ ${ }^{I}$ Student of Postgraduate Biology Education, Universitas Negeri Medan, Medan, Indonesia \\ ${ }^{2}$ Departement of Biology Education, Faculty of Mathematics and Natural Science, Universitas Negeri Medan, \\ Jl. Willem Iskandar Psr V Medan Estate-Indonesia (20221)
}

*Corresponding Author: Herbert Sipahutar, Departement of Biology Education, Faculty of Mathematics and Natural Science, Universitas Negeri Medan, Jl. Willem Iskandar Psr V Medan EstateIndonesia(20221).email: herbert_sipahutar@yahoo.com

\begin{abstract}
This study aims to investigate the comparison of motivation and learning achievements of students who were taught by using E-learning based schoology and power point media on human reproduction system in grade XI IPA SMA Negeri 1 Silimakuta. The research method which was applied was quasi experiment with the participans of all students of grade XI IPA are 160 students. The sample of research was determined by cluster random sampling technique mainly grade XI-1 was taught by using E-learning based schoology media and grade XI-2 was taught by using power point media. The research design which was used was pretest-posttest control group design. Data analysis technique used Independent Samples $t$ Test. The result of the research showed that there was comparison of students' learning motivation which was taught by using Elearning based schoology media $(89.67 \pm 3.06)$ and by using power point media $(85.63 \pm 3.45)$ was $4.72 \%$ $\left(t_{\text {count }} 4.95 ; P=0.000\right)$. There was comparison of the students' learning achievements which was taught by using E-learning based schoology media $(85.44 \pm 5.58)$ and by using the power point media $(72.53 \pm 7.93)$ was $17.79 \%\left(t_{\text {count }} 7.249 ; P=0.000\right)$. These results indicated that the use of E-learning based schoology media more contributes to improve students' motivation and learning achievements, especially in the material of the human reproduction system. Thus, researchers suggested that the use of E-learning based schoology media in the process of biology learning as one of the learning innovation efforts.
\end{abstract}

Keywords: E-learning, Schoology, Power Point, Learning Motivation, Learning Achievements

\section{INTRODUCTION}

The development of technology nowadays develops and grows rapidly including in education aspect. Digital technology in education can be used as a learning tool to help students to obtain the factual information. One of the information technology in learning is E-Learning. According to Horton (2003) E-learning is the use of internet and web technology to create learning experiences. While Hargis (2000) states the reason for using internet is because of wide information access, unlimited resources, students as active participants, the motivation influence from learning activities, students' discovery and cooperative learning. E-learning helps teachers in teaching-learning activities. By Elearning teaching, materials can be visualized in more dynamic and interactive forms so that students can be motivated to engage further in the learning process (Wahono, 2003). The use of E-learning today is not too difficult when viewed from the rapid internet users. Based on the data obtained, the total of internet users in Indonesia in 2016 reached 132.7 million people (51.8\%), university student users 10.3 million (7.8\%) and students 8.3 million (6.3\%) (Isparmo, 2016).

Traditional learning will lead boredom to students because of the lack of learning innovation, which affects the students' motivation and learning achievements since students only rely on teachers to obtain information (Pribadi et al., 2010). Based on PISA survey in 2015, the Indonesian students' science-learning motivation index is 0.65 of the average OECD index which is 0.02 with very low category (OECD, 2016). Therefore, it is highly necessary to have an interesting learning innovation for students especially on the subject material which is considered difficult for students.

The reproduction system is one of the most elusive biology material for elementary and tenth graders according to Ozcan et al (2014). In line with research conducted by Tekkaya et al (2001) said that the material reproduction is one of the material that is difficult to learn by some students. Lazarowitz et al 
(1992) in Tekkaya et al (2001) and Cimer (2012) also found that Israeli high-school students had difficulties in learning of physiological process materials. The reason why students treat biology as a difficult lesson is the low interest and motivation to learn biology (Mavrikaki et al., 2012). To overcome student's learning difficulties, it is necessary to do learning innovation which can improve students' motivation and learning achievements such as the use of online E-learning media that can be quickly and widely accessed.

One of the learning innovations which can be used is the E-learning schoology platform. Schoology is one of the Learning Management Systems (LMS) which provides facilities for teachers and students to interact each other and also exchange information via online. Schoology also enables students to download lesson material, presentation slides, video tutorials, work on quizzes, exams, discussions and submission of task which is assigned by the teacher. According to Dziuban et al (2004) in Cepik et al (2016) one of the characteristics of blended learning is increasing the interaction between students with teachers, students with students, students with materials and students with other new material. Wati's research (2015) showed that E-learning schoology can improve students' motivation and biology learning achievements in grade XII SMAN 8 with students' mastery score 8.80. Similarly, Sicat et al (2015) found that there were significant differences in students' learning achievements between group using traditional methods and experimental group using LMS schoology. Similarly, Irawan et al (2017) said that there are significant differences in learning achievements between school based blended learning and problem based learning. Trisnawati (2014) found that students' high order thinking taught by using camtasia media obtained better average value was 65.55 compared to student who was taught by power point media only obtained the average value was 59.55 .

Based on the observations conducted in SMA Negeri 1 Silimakuta, the learning process has not applied E-learning optimally. Learning is done by lecturing method, it was done in biology lesson as well. This results in low learning achievements on students. Therefore, this study suggests to provide information to teachers to be able to optimize the use of Internet by utilizing E-learning based schoology as one of the learning innovation efforts.

\section{Materials \& MethodS}

\subsection{Research Location, Population and Sample}

This research was conducted in grade XI IPA SMA Negeri 1 Silimakuta, Jalan Pendidikan, No.156 Saribu Dolok. This study was conducted since May to June 2017. The participans of this study were all students of grade XI IPA of SMA Negeri 1 Silimakuta totalling 160 students in which grade XI-1 and XI-2 were the samples determined by cluster random sampling technique (Sugiyono, 2015 ).

\subsection{Research Design and Variables}

This research is quasi experiment with pretest-postest control group design. Grade XI-1 were taught by using E-learning based schoology and grade XI-2 were taught by using power point. The independent variables are E-learning based schoology and power point, while the dependent variables are motivation and student learning achievements.

\subsection{Instruments and Data Analysis}

The research instrument were questionnaire used to find out students' learning motivation and test instrument used to know students' learning achievement. Data analysis technique applied Independent Samples t Test, data normality test used Kolmogorov - Smirnov and homogenity test data used Levene's test for equality variance. All data were analyzed using SPSS software version 22.

\section{RESUlTS \& DISCUSSION}

\subsection{Results}

Based on the results of research, the average value of students' learning motivation in E-learning based schoology class was 89.67 while in power point class, the average value was 85.63 with the difference was $4.72 \%$. Students' learning achievements using E-learning based schoology obtained an average value was 85.44 while in power point class was 72.53 with the difference was $17.79 \%$. The results of this study indicated that the students' motivation and learning achievements taught by using E-learning based schoology media was higher than using power point media.

Based on normality test result of students' learning motivation on pre-test and post-test, it was obtained that both data are normal (Table 1). 
Comparison of Motivation and Students' Learning Achievements by using E-Learning based Schoology and Power Point on Biology Material

Table1. Pre-test and Post-test Normality Results of Student learning Motivation

\begin{tabular}{|c|c|c|c|c|}
\hline \multirow{3}{*}{ Learning Media } & \multicolumn{4}{|c|}{ Kolmogorov-Smirnov } \\
\hline & \multicolumn{2}{|c|}{ Pre-test } & \multicolumn{2}{|c|}{ Post-test } \\
\hline & Sig. & Note & Sig. & Note \\
\hline E-learning based schoology & 0.200 & Normal & 0.200 & Normal \\
\hline Power point & 0.200 & Normal & 0.200 & Normal \\
\hline
\end{tabular}

The normality test result of students' learning achievement on pre-test and post-test showed that both data are normal (Table 2).

Table2. Pre-test and Post-test Normality Results of Students' Learning Achievement

\begin{tabular}{|l|l|l|l|l|}
\hline \multirow{2}{*}{\multicolumn{1}{c|}{ Learning Media }} & \multicolumn{4}{c|}{ Kolmogorov-Smirnov } \\
\cline { 2 - 5 } & \multicolumn{3}{c|}{ Pre-test } & \multicolumn{2}{c|}{ Post-test } \\
\cline { 2 - 5 } & Sig. & Note & Sig. & Note \\
\hline E-learning based Schoology & 0.162 & Normal & 0.200 & Normal \\
\hline Power Point & 0.076 & Normal & 0.200 & Normal \\
\hline
\end{tabular}

The homogenity test result of students' learning motivation on pre-test and post-test showed that both data have the same variance (homogeneous) (Table 3).

Table3. Pre-test and Post-test Homogenity Results of Students' Motivation

\begin{tabular}{|l|l|l|l|l|l|l|l|}
\hline \multirow{2}{*}{ Learning Media } & \multicolumn{4}{|c|}{ Levene's test for equality variansces } \\
\cline { 2 - 7 } & \multicolumn{4}{|c|}{ Pre-test } & \multicolumn{3}{c|}{ Post-test } \\
\cline { 2 - 7 } & $\mathrm{F}$ & Sig. & Note & $\mathrm{F}$ & Sig. & Note \\
\hline E-learning based schoology and power point & 0.465 & 0.498 & Homogen & 0.047 & 0.829 & Homogen \\
\hline
\end{tabular}

The homogenity result of students' learning achievement on pre-test and post-test showed both data have the same variance (homogeneous) (Table 4).

Table4. Pre-test and Post-test Homogenity Results of Student Learning Achievements

\begin{tabular}{|l|l|l|l|l|l|l|}
\hline \multirow{2}{*}{ Learning Media } & \multicolumn{4}{|c|}{ Levene's test for equality variansces } \\
\cline { 2 - 7 } & \multicolumn{4}{|c|}{ Pre-test } & \multicolumn{4}{c|}{ Post-test } \\
\cline { 2 - 7 } & $\mathrm{F}$ & Sig. & Note & F & Sig. & Note \\
\hline E-learning based schoology and power point & 0.154 & 0.696 & Homogen & 1.882 & 0.175 & Homogen \\
\hline
\end{tabular}

Ket: $F=$ Levene statistic

The Independent Samples t Test result showed the comparison of students' learning motivation taught by using E-learning based schoology $(89.67 \pm 3.06)$ and by using power point $(85.63 \pm 3.45)$ was $4.72 \%\left(\mathrm{t}_{\text {count }} 4.795, \mathrm{P}=0.000\right)$ can be seen in Figure 1 .

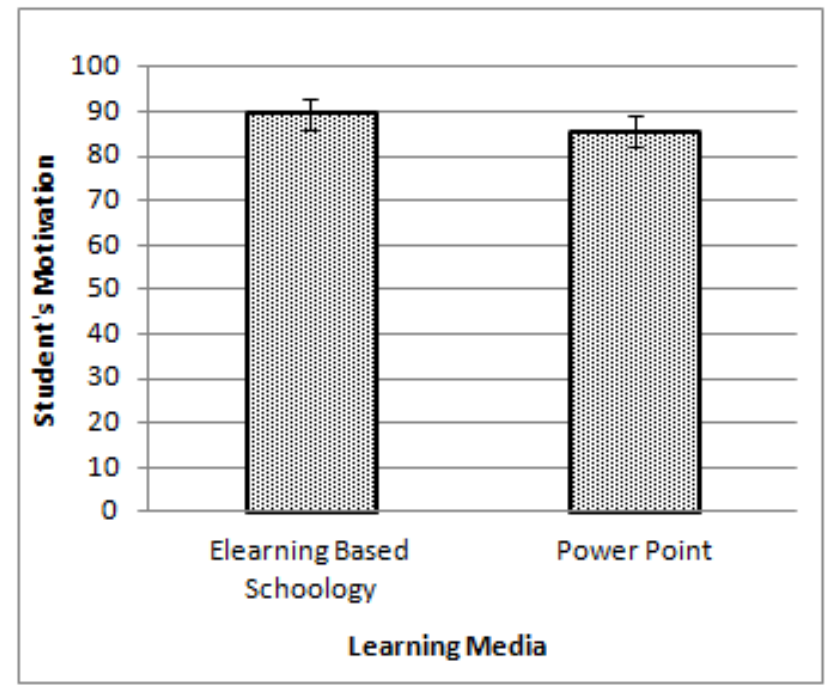

Figure1. Comparison of Students' Motivation Taught by Using E-learning Based Schoology and Power Point Media $\left(t_{\text {count }}=4.795 ; P=0.000\right)$.

Indicators of students' learning motivation consist of: (a) learning desire; (b) encouragement and learning needs; (c) expectations and future ambitions; (d) learning awards; (e) interesting activities in learning; and (f) a conducive environment. The comparison of students' learning motivation toward motivation indicators can be seen in Figure 2. 


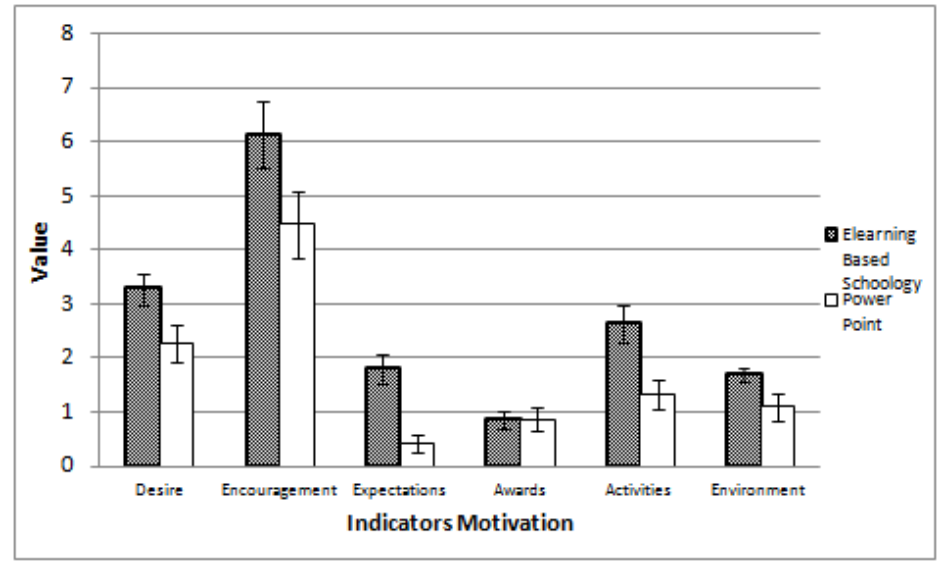

Figure2. Comparison Gain of Students' Learning Motivation on Each Indicator Using E-learning Media Based Schoology and Power Point Media. Data analysis toward indicators of desire, expectations and interesting activities in learning are significantly different while indicators of encouragement, awards and a conducive environment are significantly different

While the comparison of student's learning achievements using E-learning based schoology (85.44 \pm $5.58)$ and using power point $(72.53 \pm 7.93)$ was $17.79 \%\left(\mathrm{t}_{\text {count }} 7.249 ; \mathrm{P}=0.000\right)$ (Figure 3$)$.

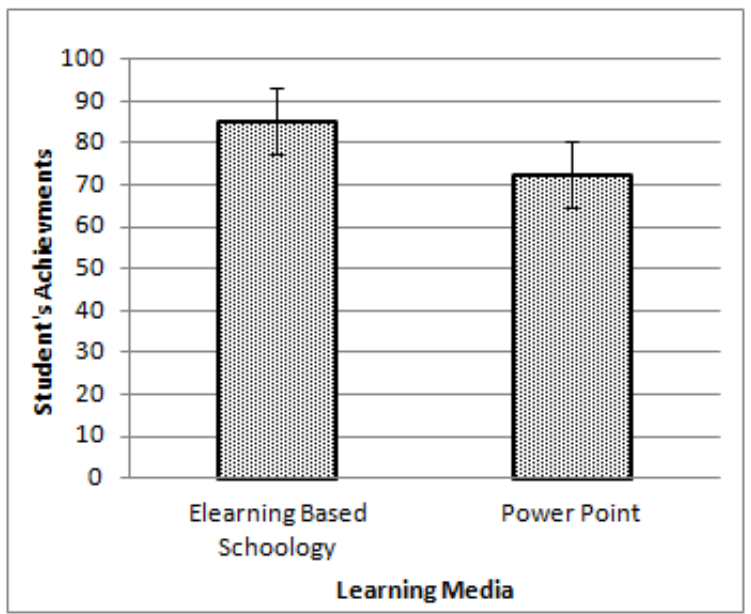

Figure3. Comparison of Students' Learning Achievements Using E-learning Media Based Schoology and Power Point Media $\left(t_{\text {count }}=7.249 ; P=0.000\right)$.

\section{DISCUSSIONS}

Based on the results of research, it was found that students' learning motivation using E-learning media based shoology was $4.72 \%$ which was higher than students' learning motivation by using power point media on human reproduction system. The increase of students' learning motivation to study in grade XI IPA SMA 1 Silimakuta during learning process was affected by the the use of digital media. Based on researchers' observations in the school, students were rarely taught by using media, especially digital online media. Therefore, when the researchers conducted learning process by using E-learning and power point media, the students were enthusiastic to follow the learning activities. They had a high spirit of learning which was marked by a number of students raised questions to their teacher. In addition to the researchers observations results, the students' enthusiasm to learn could also be seen from the average value of students' learning desire indicator was 92 and an interesting activity indicators was 88.67 in classroom-based E-learning. It showes that the enthusiasm in the observation of the researchers is in line with the results of questionnaires filled by students. Dealing with the opinion stated by Uno (2006) motivation is a psychological process that can be seen from a person's behavior and someone's encouragement to do something to achieve certain goals.

Wati (2015) in her research found that there was an increase of students' learning motivation which was $3 \%$ on students who were taught using E-learning schoology. Similarly, Syafi'i (2016) found a significant increase of students' learning motivation and learning achievements in English class by using blended learning. Hanandya in her research (2016) also showed the students' learning motivation who were taught by using schoology in English class had a high motivation, because they 
were interested, comfortable and feeling fun while doing activities in schoology. Students' learning motivation with E-learning schoology is higher than students' learning motivation with power point because on E-learning based schoology activities, students are involved in using technology during learning process. The involvement of students in using this media can increase students' curiosity and extend new experiences to use the media, thus students are eventually more active.

Students' learning achievement by using E-learning based shoology media is $17.79 \%$ which is higher than students' learning achievement by using power point media because the blended learning system based on schoology makes learning more flexible and interesting, the format of teaching materials is more varied, highly interactive and the availability of video material reproduction enables students to experience a more dynamic learning process which is considered as new experiences, thus students have high enthusiasm in following learning. O'Day (2008) suggests that animations are more effective than static sequential images to study the concept of biology materials. According to Dale (1969) the students' learning experiences increase become 30\% to 50\% if students view images, animations, videos / films and engage in learning discussions. Low (2017) found an increase in students' learning achievements was $94.64 \%$ in the summative test conducted by using E-learning based schoology media during learning process. It is in line with Burgstrom (2017) who stated that the average increase in student learning achievements' was $9.37 \%$ on students taught by using E-learning based schoology. Similarly, Kusumantara et al (2017) obtained the average of students' learning achievements using Elearning shoology was 19.33 while the average value of control class was 16.78 . It means that the class of E-learning schoology is better.

\section{CONClusion}

Based on the results and discussions, it can be concluded that there is a significant comparison of students' learning motivation and learning achievements between the use of E-learning based schoology media and power point media on human reproduction system in grade XI IPA SMA Negeri 1 Silimakuta. In other words, the use of school-based E-learning media contributes significantly to improve students' learning motivation and learning achievements than the power point media, especially on the the human reproduction system material. Therefore, researchers suggest the use of school-based E-learning media in the process of biology learning as one of the learning innovation efforts.

\section{REFERENCES}

Burgstrom, L. (2017). The Impact of Student Completion Requirements Using an LMS (Learning Management System) on Student Achievement and Differentiated Instruction in The Classroom. Education and Human Development Master's Theses. 721. http://digitalcommons.brockport.edu/ ehd_theses/721, diakses tanggal 15 oktober 2017.

Cepik, Saban., Gönen K dan Sazak M K. (2016). ELT instructors' attitudes towards the use of Blended Learning in tertiary level English language programs. International Journal of Human Sciences, 13(1): 1716-1730.

Cimer, A. (2012). What Makes Biology Learning Difficult and Effective: Students' Views. Journal Educational Research and Reviews, 7(3): 61-71.

Dale, E. (1969). Audio Visual Methods in Teaching. New York: Holt, Rinehart and Winston Inc. The Dryden press.

Hanandya. (2016). Student's Motivation in Using Schoology in Pronunciation class. Faculty of Language and Literature. Salatiga: Satya Wacana Christian University.

Hargis, J. (2000). The Self-Regulated Learner Advantage: Learning Science on the Internet. Electronic Journal of Education, 4(4).

Horton, W dan Horton, K. (2003). E-learning Tools and Technologies: A consumer guide for trainers, teachers, educators, and instructional designers. USA : Wiley Publishing, Inc.

Irawan, V T., Eddy Sutadji dan Widiyanti. (2017). Blended Learning Based on Schoology: Effort of Improvement Learning Outcome and Practicum Chance in Vocational High School. Curriculum \& Teaching Studies Research Article. Journal Cogent Education, 4: 1282031.

Isparmo. (2016). Data Statistik Pengguna Internet Indonesia Tahun 2016.http://isparmo.web.id/ 2016/11/21/data-statistik-pengguna - internet indonesia-2016/, diakses tanggal 19 Januari 2017.

Kusumantara, K.S., Gede, S.S dan Nyoman, S. (2017). Pengaruh E-learning Schoology terhadap Hasil Belajar Simulasi Digital dengan Model Pembelajaran Savi. Jurnal Pendidikan Teknologi dan Kejuruan, 14(2): 126.

Low, P. (2017). E-learning Implementation in Foundation English Class: Learners' Perspectives and Learning Achievement. International Journal of Computer Theory and Engineering, 9( 4): 285-289. 
Mavrikaki, E., Koumparou H., Kyriakoudi M., Papacharalampous I dan Trimandili M. (2012). Greek Secondary School Students' Views About Biology. International Journal of Environmental \& Science Education. 7(2): 217-232.

OECD. (2016). PISA 2015 Results in Focus. OECD (Organization for Economic Cooperation and Development) Better Policies for Better Lives.

O’Day, D.H. (2008). Using Animations To Teach Biology: Past \& Future Research on the Attributes that Underlie Pedagogically Sound Animations. Jurnal The American Biology Teacher, 70(5):274-278.

Ozcan, T., Ozgur S., Aybuke K dan Elgun S. (2014). Identifiying and Comparing the Degree of Difficulties Biology Subjects By Adjusting It is Reasons in Elemantary and Secondary Education. Journal Elsevier Procedia - Social and Behavioral Sciences, 116 (2014): 113 - 122.

Pribadi, A dan Benny. (2010). Model Desain Sistem Pembelajaran. Jakarta: Dian Aksara.

Sicat, AS dan Ed, MA. (2015). Enhancing College Students' Proficiency in Business Writing Via Schoology. International Journal of Education and Research, 3 (1):159-178.

Sugiyono. 2015. Metode Penelitian Manajemen Pendekatan Kuantitatif, Kualitatif, Kombinasi, Penelitian Tindakan, Penelitian Evaluasi. Bandung: Alfabeta.

Syafi'i, A. (2016). Blended Learning To Enhance Students' Motivation And English Achievement at SMKN 3 Metro. Master In English Language Teaching.

Tekkaya, C., Ozkan O dan Sungur S. (2001). Biology Concepts Perceived As Difficult By Turkish High School Students. Hacettepe Üniversitesi Eğitim Fakültesi Dergisi 21: 145-150.

Trisnawati, G. 2014. Perbandingan Penggunaan Media Pembelajaran Camtasia dan Power point dengan Penerapan Strategi Pembelajaran Langsung terhadap Kemampuan Berpikir Tingkat Tinggi dan Retensi Memori Biologi Siswa Kelas X SMA N 12 Medan. Tesis Pascasarjana Pendidikan Biologi. Medan: Universitas Negeri Medan.

Uno, H B. (2006). Teori Motivasi dan Pengukurannya. Jakarta: Bumi Aksara.

Wahono, RS. (2003). Pengantar E-learning dan Pengembangannya. www.ilmukomputer.com, diakses tanggal 9 Mei 2016.

Wati, A. (2015). Peningkatan Motivasi dan Hasil Belajar Biologi Siswa Kelas XII melalui Penerapan Pembelajaran E-learning Schoology SMAN 8 Pekanbaru Riau. Jurnal Pendidikan, 1(1): 52-60.

AUTHORS' BIOGRAPHY

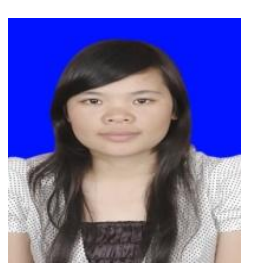

Asmariati Purba, S.Pd, is a biology education postgraduate student at Postgraduate Programe of Universitas Negeri Medan (State University of Medan), Medan, North Sumatera, Post code 20221, Indonesia. She obtained her Sarjana Degree (S1) in Biology Education from Universitas Negeri Medan, her obtaining Master Programe in Biology Education on Universitas Negeri Medan.

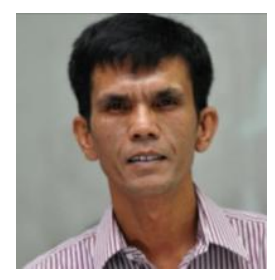

Prof. Dr. Herbert Sipahutar, M.S., M.Sc, is a professor in cell and molecular biology of the Biology Education Study at Graduate and Postgraduate Programe of Universitas Negeri Medan (Medan State University), Medan, North Sumatera, Post code 20221, Indonesia. He obtained his Sarjana Degree (S1) in Biology Education from IKIP Medan, his Master Degree (S2) in Biology from ITB Bandung and also in Zoology from University of Tasmania, Australia. His Doctor Degree (S3) in cell and molecular biology from Universite' de Caen, France.

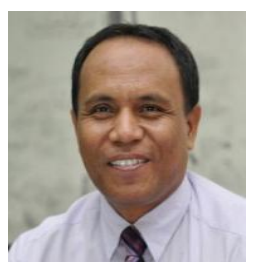

Dr. Syahmi Edi, M. Si, is a Lecturer at Graduate and Postgraduate Programe of Universitas Negeri Medan (Medan State University), Medan, North Sumatera, Post code 20221, Indonesia. He obtained his Sarjana Degree (S1) in Biology Programe from Universitas Negeri Andalas, his Master Degree (S2) in Biology Programe from Institut Pertanian Bogor and his Doctor Degree (S3) in Biology Programe from Institut Pertanian Bogor.

Citation: Asmariati Purba, et al. " Comparison of Motivation and Students' Learning Achievements by using E-Learning based Schoology and Power Point on Biology Material "International Journal of Humanities Social Sciences and Education (IJHSSE), vol 4, no. 11, 2017, pp. 208-213. doi: http://dx.doi.org/10.20431/23490381.0411024.

Copyright: (C) 2017 Authors. This is an open-access article distributed under the terms of the Creative Commons Attribution License, which permits unrestricted use, distribution, and reproduction in any medium, provided the original author and source are credited. 